\title{
NOCTURNAL AGGREGATIONS OF WHITE-TAILED JACK-RABBITS AT RIMBEY, ALBERTA
}

DANIEL F. BRUNTON, 2683 Violet Street, Ottawa, Ontario K2B 6X1.

The recent series of notes concerning concentrations of White-tailed Jackrabbits (Lepus townsendii) in southern Saskatchewan ${ }^{3} 5$ reminded me of similar observations that I made during the winter of 1976-1977 in southern Alberta. The major difference between the Saskatchewan observations and those reported herein is that my observations involve nocturnal activities.

Sightings were made at the northeastern edge of the village of Rimbey, Alberta $\left(51^{\circ} 39^{\prime} \mathrm{N}, 114^{\circ} 14^{\prime} \mathrm{W}\right)$ about $50 \mathrm{~km}$ northwest of Red Deer. This is situated just west of the range of the species as illustrated by Banfield ${ }^{2}$ but others have recorded the hare in this area before. ' Observations were made during mid to late December 1976 (exact dates not recorded).

For about a 10 day period, large aggregations of jack-rabbits were observed daily in an open fallow field immediately adjacent to urban development. The observations were made from about $2000 \mathrm{hrs}$. to at least 2300 hrs. The number of animals present varied considerably, from a minimum of 30 to a maximum of $125-150$. Typically, approximately 100 jackrabbits were seen on any given night in this period. The hares were relatively evenly distributed over an open area of approximately $300 \times 400 \mathrm{~m}$. These estimates were arrived at by traversing the field by automobile. The snow depth was very low at the time (10 $\mathrm{cm}$ or less), which favoured vehicular access and apparently encouraged the presence of the animals as well.
Observations were not continued in January 1977 as increased snow dept prohibited vehicular access and hence full coverage of the field. Tracks in th snow suggested, however, that th night-time aggregations continued least into mid-January.

With limited prior experience of th species (having just moved into th range of the animal), I was not aware the time that this behaviour wa particularly unusual. It seeme reasonable to assume that th abundance of food provided sufficie appeal for many of the area's jack rabbits. I was, nonetheless, surprised $k$ the number of animals involved in the aggregations. These large numbers a even more surprising in light Banfield's remark that the White-taile Jack-rabbit ". . . seems to be one of th least sociable of the [hares]."2

The hares were very actively feedir - unlike those observed by Lahrman Saskatchewan which spent most of the time sleeping. ${ }^{5}$ Banfield ${ }^{2}$ notes that th species is primarily nocturnal; althoug my home was adjacent to the "rabk field", I did not see any hares durir day-light hours. The animals we feeding primarily on Alfalfa (Medicas sativa) that was commonly expose throughout the field. This is cited as : important summer food of White-taile Jack-rabbits ${ }^{2}$, as are twigs, buds ar bark in winter. There was no shrubbe at all in the Rimbey site.

Unlike the animals observed Lahrman ${ }^{5}$, the Rimbey hares were $n$ 
wary. They would run to one side to permit the passage of the automobile but rarely moved farther than $20 \mathrm{~m}$ away and (after a brief period) would resume feeding. My use of high-beam headlights on the vehicle did not seem to affect the animals differently.

I was unable to observe any sign of conflict - or other social interaction amongst the hares. Each seemed more intent on feeding than on the presence of observers or other jack-rabbits.
'ACORN, J. 1980. 83A-6 Gull Lake, in D Spaulding (Editor), A Nature Guide to Alberta, Hurtig Publishers, Edmonton.

${ }^{2}$ BANFIELD, A. W. F. 1974. The Mammals of Canada, University of Toronto Press, Toronto.

3JACKSON, J. W. 1980. More Jack Rabbits. Blue Jay 38:267.

${ }^{4}$ KREBA, R. 1980. Fearless Jack Rabbits Blue Jay 38:130-131.

${ }^{5}$ LAHRMAN, F. W. 1980. A Concentration of White-tailed Jack Rabbits. Blue Jay 38: 130 .

\section{RIVER OTTER SIGHTINGS IN SOUTHERN SASKATCHEWAN}

GLEN SUGGETT, 235 Lockwood Street, Winnipeg, Manitoba. R3N 1S1 and RIAN KEATING, Prairie Wildlife Interpretation Centre, P.O. Box 10, Webb, Saskatchewan. SON $2 \times 0$.

Two separate sightings of River tters were made in the prairies of outhern Saskatchewan in summer 980. Glen Suggett observed a single iver Otter on August 25 at the north nd of Moose Mountain Lake in the outheastern corner of the province. He nd Brian Keating observed another on ctober 4 at the mouth of Swift Current reek, where it enters the South Sasktchewan River. Otters are easily istinguished from mink, which they semble in colouration, by their larger ze and characteristic loping gait when inning on land.

Banfield's Mammals of Canada iggests that the River Otter is xtirpated in the prairie region of anada, but otters have been known to avel great distances in search of itable habitat. The north end of Moose ountain Lake, where Moose Mountain
Creek enters, and the mouth of Swift Current Creek both provide habitat that fulfills the otter's needs. Moose Mountain Creek, interrupted by several Beaver dams, retained a good supply of water, in spite of the drought experienced last summer. The lake, creek, and adjoining marshlands provided an abundance of amphibians and fish, the mainstays of the otter's diet. Numerous White Pelicans, Doublecrested Cormorants, and Great Blue Herons were also observed partaking of this source of protein rich food. Swift Current Creek similarly supplied a healthy population of Leopard Frogs, Minnows and other coarse fish, in addition to an assured supply of water. It lacks the concealment of the emergent vegetation found in Moose Mountain Creek, but it is an isolated spot characterized by steep valley sides, patches of dense brush, and a thin band 